\title{
Unmet Need for Family Planning Among Married Women in Sub- Sahara Africa: A Meta-Analysis of DHS Data (1995 - 2020)
}

Million Phiri ( $\square$ millsphiri@gmail.com)

University of the Witwatersrand

\section{Clifford Odimegwu}

University of the Witwatersrand

\section{Chester Kalinda}

University of KwaZulu-Natal, Howard College Campus

\section{Research Article}

Keywords: Prevalence, Unmet need, Family planning, Meta-analysis, Sub-Saharan Africa.

Posted Date: January 20th, 2022

DOI: https://doi.org/10.21203/rs.3.rs-955281/v2

License: (ㅇ (i) This work is licensed under a Creative Commons Attribution 4.0 International License. Read Full License 


\section{Abstract}

Background: Closing the gap of unmet needs for family planning (FP) in sub-Saharan Africa remains critical in improving maternal and child health outcomes. Determining the prevalence of unmet needs for family planning among married women in the reproductive age is vital for designing effective sexual reproductive health interventions and programmes. Here, we use nationally representative data drawn from sub-Saharan countries to estimate and examine heterogeneity of unmet needs for family planning among currently married women of reproductive age.

Methods: This study used secondary data from Demographic and Health Surveys (DHS) conducted between January 1, 1995 to December 31, 2020 from 37 countries in sub-Saharan African. An Inverse Heterogeneity model (IVhet) in MetaXL application was used to estimate country and sub-regional level pooled estimates and confidence intervals of unmet needs for FP in SSA.

Results:The overall prevalence of unmet need for family planning among married women of reproductive age in the sub-region for the period under study was $22.9 \%$ (95\% Cl: $20.9-25.0)$. The prevalence varied across countries from $10 \%(95 \% \mathrm{Cl}: 10-11 \%)$ in Zimbabwe to 38\% (95\% Cl: $35-40)$ and 38 (95\% Cl: 37-39) (I2 = 99.8\% and p-value <0.0001) in Sao Tome and Principe and Angola, respectively. Unmet needs due to limiting ranged from 6\%; (95\% Cl: 3-9) in Central Africa to 9\%; (95\% Cl: 8-11) in East Africa. On the other hand, the prevalence of unmet needs due to spacing was highest in Central Africa (Prev: 18; 95\% Cl: 16-21) and lowest in Southern Africa (Prev: 12\%; 95\% Cl: 8-16). Our study indicates that there was no publication bias because the Luis Furuya-Kanamori index (0.79) was within the symmetry range of -1 and +1 .

Conclusion: The prevalence of unmet need for FP remains high in sub-Saharan Africa suggesting the need for health policymakers to consider re-evaluating the current SRH policies and programmes with the view of redesigning the present successful strategies to address the problem.

\section{Introduction}

Attainment of universal access to sexual and reproductive health (SRH) services including family planning and achieving the Sustainable Development Goals (SDGs)SDG 3 and 5 requires deliberate and concerted policyefforts[1]. Thus, addressing factors and challenges such as sexual and reproductive health issues, unintended pregnancies, high fertility and unsafe abortions among women in the reproductive age should remain a priority [2, 3] Earlier studies by Ahmed et al. [4] and Ajayi et al. [5]have suggested thatimproved maternal health outcome is highly dependent on health care visits, risingdemand, access, and uptake of contraceptives. Although several women in developing countries especially in sub-Saharan Africa (SSA) understand the importance of family planning (FP), many have unmet needs for FP[6, 7].

Family planning (FP) is pivotal in the improvement of maternal and childhealth [8] and return-on-investment strategies [9].Following the 2012 London Summit onFP and the FP2020 initiative byBill and Melinda Gates Foundation, the UK Department for International Development, the United States Agency for International Development (USAID), and the United Nations Population Fund (UNFPA) whose target is to reach 120 million new users of modern contraceptives in developing countries by the year 2020[10, 11], there has been a revivalin the needs for FP. However, the success of the FP2020 has not been attained partly due to the inability to track annual progress and delayed uptake of modern contraceptives[10]thus, increasing the gap in unmet needs for FP in developing countries [7, 12]. Calls to strengthen FP programmes in SSAto reduce unmet needs have been on the increase[13] as this influences regional and country-level decision making in attaining SDG 3.7.1. Therefore, estimating country level and regional prevalence ofunmet needs for family planning would be key in evaluating country level FP programmes and interventions to guide policymakerson how to improve maternal and child health through improved resource allocation and redesigning of existing programmes.

Determining the prevalence of unmet need for family planning among women in the reproductiveage is critical in measuring progress towards improving maternal and child health. There has been progress in understanding the factors that influence family planning[14-16], howeverunmet needs especially at the sub-regional level remains a challenge[7, 17].Several earlier studies have determined unmet needs among young women [18], sex workers [19] and HIV positive women [20, 21]. Several studies on the unmet need for family planning have been published in other parts of the world. Many of the studies in SSA have focused mainly on examining country level prevalenceand factors associated with unmet needfor FP but neglected analyses of country and regional variations. At both country and sub-regional level, many factors such as socio-economic characteristics, religious beliefs, cultural beliefs, fertility norms, health behavior and prior SRH interventions can explain variations ofthe prevalence of family planning 
indicators [40]. However, a pooled analysis of the prevalence of unmet needs for FP using nationally representative data would be essential in providing a holistic regional picture as well assub-regional differences. Data on regional variations is important to guide the identification and documentation of countries with best practices on SRH policy and programming. This data is usefulto informredesigning and implementation of maternal health programs in countries where the problem still exists. Here, we apply meta-analysis to determine the pooled prevalence and examine heterogeneity ofunmet needs for family planning in SSAbased on country level latest nationally-representative Demographic and Health Surveys (DHS) (collected between 1995 and 2020) from 37 countries. Furthermore, data from meta-analysis would be useful to support generation of evidence-based information to guide sharping SRH policy and programme design and implementation at country and sub-regional levels[22, 23].

\section{Methods}

\section{Data sources}

The data analysed in this study were extracted from thecountry latest Demographic and health survey (DHS) collected between 1995 and2020 in 37 SSA countries. The datasets are publicly available from the DHS websitehttps://dhsprogram.com/[24]. The surveys are periodical nationally and population-based comprising large sample sizes which may vary between 5000 and 30,000. To enable comparisons among countries and sub-regions, DHS uses a standard sampling design using probability proportional to size when determining country level sample size. The DHS collate data using standardized questionnaires comprising: a household questionnaire, a women's questionnaire, a men's questionnaireand the biomarker questionnaire. Furthermore,DHS surveysusually use two-stage stratified,(cluster), random sampling designs which involve the selection of enumeration areas in stage one and random selection of households in the second stage.In all selected households, women in the reproductive age 15-49 years are eligible to participate while men aged 15-59 years are also eligible to participate. Details on data collection and sampling methodology used by DHS are described elsewhere[24].

\section{Study selection and inclusion criteria.}

All sub-Saharan African countries with available DHS (1995-2020) and comprehensive data on the prevalence of unmet needs for family planning were included in this study. Countries with the latest DHS from 1994/5 to 2020 were eligible to capture the trend in unmet needs for family planning in SSA. Furthermore, including data in this period was used to give a holistic picture of unmet needs for family planning in SSA considering that some countries may be without the most recent DHS datasets. The selection criteria of countries to be included was summarized in the Preferred Reporting Items for Systematic Reviews and Meta-Analysis (PRISMA)diagram presented in Figure 1. PRISMA is an evidence-based set of standard procedure to guide process of determining inclusion and exclusion criteria for reporting systematic and meta-analyses [39]. The sub-regional classification of countries in SSA is based on the United Nations (UN) geoscheme classification for SSA.

\section{Data extracted}

Data sourced from the DHS program website included DHS datasets for 37 countries in sub-Saharan Africa conducted in the period 1995 -2020. The information extracted from the country-level datasets included the name of the country, year of DHS implementation, weighted country samples of married women $15-49$, number of women who needed family planning, number of women with unmet need for FP, number of women with unmet need for spacing, number of women with unmet need for limiting and names of sub-regions where each country belong (Table 1). The outcome variable for the study, Unmet Need for family planning was defined as the number of women currently married or in union who are fecund and desire to either terminate or postpone childbearing, but are not currently using a contraceptive method[24].

Table 1: Distribution of women of reproductive age (15-49) with family need in sub-Saharan Africa 1995 - 2020 


\begin{tabular}{|c|c|c|c|c|c|c|c|c|c|}
\hline Country & $\begin{array}{l}\text { DHS } \\
\text { Year }\end{array}$ & $\begin{array}{l}\text { Weighted } \\
\text { sample } \\
\text { size }\end{array}$ & $\begin{array}{l}\text { Number } \\
\text { of } \\
\text { women } \\
\text { who } \\
\text { need } \\
\text { FP }\end{array}$ & $\begin{array}{l}\text { Number of } \\
\text { married } \\
\text { women with } \\
\text { unmet need } \\
\text { for FP }\end{array}$ & $\begin{array}{l}\text { Number of } \\
\text { married } \\
\text { women with } \\
\text { unmet for } \\
\text { Spacing }\end{array}$ & $\begin{array}{l}\text { Number of } \\
\text { married } \\
\text { women with } \\
\text { unmet for } \\
\text { limiting }\end{array}$ & $\begin{array}{l}\text { Data } \\
\text { Source }\end{array}$ & $\begin{array}{l}\text { Unit of } \\
\text { analysis }\end{array}$ & $\begin{array}{l}\text { Sub- } \\
\text { Region }\end{array}$ \\
\hline Angola & 2016 & 7,957 & 4,114 & 3,024 & 2,077 & 947 & DHS & $\begin{array}{l}\text { Married } \\
\text { women } \\
15-49\end{array}$ & $\begin{array}{l}\text { Southern } \\
\text { Africa }\end{array}$ \\
\hline Benin & 2018 & 11,168 & 5,338 & 3,607 & 2,535 & 1,072 & DHS & $\begin{array}{l}\text { Married } \\
\text { women } \\
15-49\end{array}$ & $\begin{array}{l}\text { West } \\
\text { Africa }\end{array}$ \\
\hline Burkina Faso & 2010 & 13,563 & 5,520 & 3,323 & 2,414 & 909 & DHS & $\begin{array}{l}\text { Married } \\
\text { women } \\
15-49\end{array}$ & $\begin{array}{l}\text { West } \\
\text { Africa }\end{array}$ \\
\hline Burundi & 2017 & 9,782 & 5,703 & 2,905 & 1,575 & 1,330 & DHS & $\begin{array}{l}\text { Married } \\
\text { women } \\
15-49\end{array}$ & $\begin{array}{l}\text { East } \\
\text { Africa }\end{array}$ \\
\hline Cameroon & 2018 & 9,792 & 4,152 & 2,252 & 1,469 & 793 & DHS & $\begin{array}{l}\text { Married } \\
\text { women } \\
15-49\end{array}$ & $\begin{array}{l}\text { West } \\
\text { Africa }\end{array}$ \\
\hline $\begin{array}{l}\text { Central } \\
\text { African } \\
\text { Republic }\end{array}$ & 1995 & 4,083 & 1,380 & 780 & 559 & 216 & DHS & $\begin{array}{l}\text { Married } \\
\text { women } \\
15-49\end{array}$ & $\begin{array}{l}\text { Central } \\
\text { Africa }\end{array}$ \\
\hline Chad & 2015 & 13,263 & 3,793 & 3,037 & 2,533 & 504 & DHS & $\begin{array}{l}\text { Married } \\
\text { women } \\
15-49\end{array}$ & $\begin{array}{l}\text { Central } \\
\text { Africa }\end{array}$ \\
\hline Comoros & 2012 & 3,261 & 1,686 & 1,053 & 776 & 280 & DHS & $\begin{array}{l}\text { Married } \\
\text { women } \\
15-49\end{array}$ & $\begin{array}{l}\text { East } \\
\text { Africa }\end{array}$ \\
\hline Congo & 2012 & 6,289 & 3,968 & 1,157 & 924 & 226 & DHS & $\begin{array}{l}\text { Married } \\
\text { women } \\
15-49\end{array}$ & $\begin{array}{l}\text { Central } \\
\text { Africa }\end{array}$ \\
\hline $\begin{array}{l}\text { Congo } \\
\text { Democratic } \\
\text { Republic }\end{array}$ & 2014 & 12,096 & 5,818 & 3,351 & 2,504 & 835 & DHS & $\begin{array}{l}\text { Married } \\
\text { women } \\
15-49\end{array}$ & $\begin{array}{l}\text { Central } \\
\text { Africa }\end{array}$ \\
\hline Cote d'Ivoire & 2012 & 6,309 & 2,858 & 1,710 & 1,237 & 473 & DHS & $\begin{array}{l}\text { Married } \\
\text { women } \\
15-49\end{array}$ & $\begin{array}{l}\text { West } \\
\text { Africa }\end{array}$ \\
\hline Eswatini & 2007 & 2,062 & 1,555 & 509 & 138 & 373 & DHS & $\begin{array}{l}\text { Married } \\
\text { women } \\
15-49\end{array}$ & $\begin{array}{l}\text { Southern } \\
\text { Africa }\end{array}$ \\
\hline Ethiopia & 2016 & 10,223 & 5,950 & 2,280 & 1,329 & 951 & DHS & $\begin{array}{l}\text { Married } \\
\text { women } \\
15-49\end{array}$ & $\begin{array}{l}\text { East } \\
\text { Africa }\end{array}$ \\
\hline Gabon & 2012 & 4,475 & 2,578 & 1,186 & 837 & 345 & DHS & $\begin{array}{l}\text { Married } \\
\text { women } \\
15-49\end{array}$ & $\begin{array}{l}\text { Central } \\
\text { Africa }\end{array}$ \\
\hline Gambia & 2020 & 7,525 & 3,243 & 1,821 & 1,400 & 421 & DHS & $\begin{array}{l}\text { Married } \\
\text { women } \\
15-49\end{array}$ & $\begin{array}{l}\text { West } \\
\text { Africa }\end{array}$ \\
\hline Ghana & 2014 & 5,321 & 3,022 & 1,591 & 926 & 665 & DHS & $\begin{array}{l}\text { Married } \\
\text { women } \\
15-49\end{array}$ & $\begin{array}{l}\text { West } \\
\text { Africa }\end{array}$ \\
\hline Guinea & 2018 & & 2,542 & & & & DHS & Married & West \\
\hline
\end{tabular}




\begin{tabular}{|c|c|c|c|c|c|c|c|c|c|c|}
\hline & & 7,727 & & 1,708 & 1,190 & 510 & & & $\begin{array}{l}\text { women } \\
15-49\end{array}$ & Africa \\
\hline Kenya & 2014 & 18,549 & 14,004 & 3,246 & 1,707 & 1,540 & & DHS & $\begin{array}{l}\text { Married } \\
\text { women } \\
15-49\end{array}$ & $\begin{array}{l}\text { East } \\
\text { Africa }\end{array}$ \\
\hline Lesotho & 2014 & 3,612 & 2,839 & 665 & 307 & 358 & & DHS & $\begin{array}{l}\text { Married } \\
\text { women } \\
15-49\end{array}$ & $\begin{array}{l}\text { Southern } \\
\text { Africa }\end{array}$ \\
\hline Liberia & 2020 & 5,386 & 3,145 & 1,799 & 1,104 & 695 & & DHS & $\begin{array}{l}\text { Married } \\
\text { women } \\
15-49\end{array}$ & $\begin{array}{l}\text { West } \\
\text { Africa }\end{array}$ \\
\hline Madagascar & 2009 & 12,039 & 7,091 & 2,287 & 1,228 & 1,059 & & DHS & $\begin{array}{l}\text { Married } \\
\text { women } \\
15-49\end{array}$ & $\begin{array}{l}\text { Southern } \\
\text { Africa }\end{array}$ \\
\hline Malawi & 2016 & 16,130 & 12,565 & 3,016 & 1,742 & 1,274 & & DHS & $\begin{array}{l}\text { Married } \\
\text { women } \\
15-49\end{array}$ & $\begin{array}{l}\text { Southern } \\
\text { Africa }\end{array}$ \\
\hline Mali & 2018 & 8,567 & 3,521 & 2,048 & 1,439 & 608 & & DHS & $\begin{array}{l}\text { Married } \\
\text { women } \\
15-49\end{array}$ & $\begin{array}{l}\text { West } \\
\text { Africa }\end{array}$ \\
\hline Mozambique & 2015 & 9,332 & 4,685 & 1,530 & 1,530 & 625 & & DHS & $\begin{array}{l}\text { Married } \\
\text { women } \\
15-49\end{array}$ & $\begin{array}{l}\text { Southern } \\
\text { Africa }\end{array}$ \\
\hline Namibia & 2013 & 3,121 & 2,297 & 546 & 284 & 262 & & DHS & $\begin{array}{l}\text { Married } \\
\text { women } \\
15-49\end{array}$ & $\begin{array}{l}\text { Southern } \\
\text { Africa }\end{array}$ \\
\hline Niger & 2012 & 9,881 & 2,954 & 1,581 & 1,314 & & 267 & DHS & $\begin{array}{l}\text { Married } \\
\text { women } \\
15-49\end{array}$ & $\begin{array}{l}\text { West } \\
\text { Africa }\end{array}$ \\
\hline Nigeria & 2018 & 29,090 & 10,327 & 5,498 & 3,520 & 1,978 & & DHS & $\begin{array}{l}\text { Married } \\
\text { women } \\
15-49\end{array}$ & $\begin{array}{l}\text { West } \\
\text { Africa }\end{array}$ \\
\hline Rwanda & 2015 & 6,982 & 5,041 & 1,320 & 747 & 580 & & DHS & $\begin{array}{l}\text { Married } \\
\text { women } \\
15-49\end{array}$ & $\begin{array}{l}\text { East } \\
\text { Africa }\end{array}$ \\
\hline $\begin{array}{l}\text { Sao Tome } \\
\text { and Principe }\end{array}$ & 2009 & 1,718 & 1,306 & 646 & 309 & 337 & & DHS & $\begin{array}{l}\text { Married } \\
\text { women } \\
15-49\end{array}$ & $\begin{array}{l}\text { Central } \\
\text { Africa }\end{array}$ \\
\hline Senegal & 2019 & 10,895 & 4,195 & 2,364 & 1,765 & 588 & & DHS & $\begin{array}{l}\text { Married } \\
\text { women } \\
15-49\end{array}$ & $\begin{array}{l}\text { West } \\
\text { Africa }\end{array}$ \\
\hline Sierra Leone & 2019 & 9,714 & 4,478 & 2,409 & 1,690 & 719 & & DHS & $\begin{array}{l}\text { Married } \\
\text { women } \\
15-49\end{array}$ & $\begin{array}{l}\text { West } \\
\text { Africa }\end{array}$ \\
\hline South Africa & 2016 & 3,050 & 2,120 & 454 & 186 & 268 & & DHS & $\begin{array}{l}\text { Married } \\
\text { women } \\
15-49\end{array}$ & $\begin{array}{l}\text { Southern } \\
\text { Africa }\end{array}$ \\
\hline Tanzania & 2016 & 8,210 & 4,967 & 1,814 & 1,273 & 542 & & DHS & $\begin{array}{l}\text { Married } \\
\text { women } \\
15-49\end{array}$ & $\begin{array}{l}\text { East } \\
\text { Africa }\end{array}$ \\
\hline Togo & 2014 & 6,281 & 3,360 & 2,110 & 1,369 & 741 & & DHS & $\begin{array}{l}\text { Married } \\
\text { women } \\
15-49\end{array}$ & $\begin{array}{l}\text { West } \\
\text { Africa }\end{array}$ \\
\hline Uganda & 2016 & 11,223 & 7,553 & 3,187 & 2,054 & 1,134 & & DHS & $\begin{array}{l}\text { Married } \\
\text { women } \\
15-49\end{array}$ & $\begin{array}{l}\text { East } \\
\text { Africa }\end{array}$ \\
\hline
\end{tabular}




\begin{tabular}{|c|c|c|c|c|c|c|c|c|c|c|}
\hline Zambia & 2018 & 7,648 & 5,300 & 1,507 & 925 & 581 & & DHS & $\begin{array}{l}\text { Married } \\
\text { women } \\
15-49\end{array}$ & $\begin{array}{l}\text { Southern } \\
\text { Africa }\end{array}$ \\
\hline Zimbabwe & 2015 & 6,151 & 4,749 & 640 & 369 & & 271 & DHS & $\begin{array}{l}\text { Married } \\
\text { women } \\
15-49\end{array}$ & $\begin{array}{l}\text { Southern } \\
\text { Africa }\end{array}$ \\
\hline
\end{tabular}

\section{Data analysis}

This study was based on secondary data analysis. Meta-analyses were performed with MetaXLapplication(Version 5.3, EpiGear International Pty Ltd, QLD, Australia). MetaXL tool is auser-friendly Microsoft Excel application used to perform meta-analysis.Metaanalysis is a term that refers to a set of statistical approaches for examining the impacts of a relationship between an independent and a dependent variable. Meta-analysis allows researchers to assess a wide range of effect sizes and heterogeneity across many studies. A forest plot and supporting statistics, like as confidence and prediction intervals, are used to display the basic outcomes of meta-analyses. Additional analyses performed by this statisticalapplication tool include sub-group analysis and publication bias[23, $25,26]$. Meta-analyses are useful because they improve the generalizability of individual study results by providing a more exact estimate of the effect size[25]. Meta-analyses can improve statistical power and produce research results that can support generation of information to inform evidence-based decisions for policy and programme improvement[23].

In this study, the overall prevalence and its associated $95 \%$ confidence intervals (Cl) for pooled and unmet needs, unmet needs due to limiting and spacing were calculated. Country-specific estimates were also calculated and pooled using the Inverse Heterogeneity model (IVhet) meta-analysis to yield 37 country estimates of FP indicators[25]. The inverse variance heterogeneity (IVhet) model is meta-analyse technique which is used to assess heterogeneity trends across studies. To account for study heterogeneity, the IVhet model generates a pooled estimate with a substantially broader confidence interval. The IVhet model maintains a correct coverage probability at a lower detected variance [26].Sub-regional (West Africa, Central, East Africa or Southern Africa) and time stratified in 5 years periods (periods duringwhich DHS data is collected)prevalence was also pooled.

Forest plots were used to display the estimated prevalence in individual countries and the pooled prevalence in each sub-region and its associated $95 \%$ confidence intervals $(\mathrm{Cl})$. Heterogeneity was quantitatively evaluated with the $\mathrm{I}^{2}$ statistic while publication bias was assessed using the Luis Furuya-Kanamori (LFK) index of the Doi plot [25]. Publication bias was examined to assess the extent to which the studies accurately measured the effect sizes of family planning indicators. A symmetrical Doi plot indicates that there is no reason to infer publishing bias, whereas an asymmetrical one does [23].

\section{Results}

In total, 37 DHS datasets were eligible for final inclusion in the study, and these were drawn from four sub-regions of SSA (Figure 1). The countries included 6 (16.2\%) (Central African Republic, Chad, Congo, Congo Democratic Republic, Gabon and Sao Tome and Principe) from Central Africa,7 (18.9\%) (Burundi, Ethiopia, Kenya, Rwanda, Tanzania, Uganda and Comoros) from East Africa, 10 (27.0\%)(Angola, Eswatini, Lesotho, Madagascar, Malawi, Mozambique, Namibia, South Africa, Zambia and Zimbabwe) from Southern Africa and 14 (37.8\%) (Benin, Burkina Faso, Cameroon, Cote d'Ivoire, Gambia, Ghana, Guinea, Liberia, Mali, Niger, Nigeria, Senegal, Sierra Leone, Togo) from West Africa. Furthermore, 13.5\% $(n=5)$ had their latest DHS conducted between 1995/6-2010 cycle while 40.5\% ( $n=15)$ and 45.9\% ( $n=17)$ had their latest DHS conducted between 2011-2015 and 2016-2020 cycles, respectively.

\section{Prevalence of Unmet needs}

The overall pooled prevalence of unmet needs for family planningfor all 37 countries in the four sub-regions of SSA was 22.9\% (95\% Cl: $20.9-25.0)$. The prevalence varied across countries from $10 \%$ (95\% Cl: $10-11 \%$ ) in Zimbabwe to $38 \%$ (95\% Cl: 35-40) and 38 (95\% Cl: 37-39) ( $1^{2}=99.8 \%$ and p-value $\left.<0.0001\right)$ in Sao Tome and Principe and Angola, respectively. Twenty-four countries had the prevalence of unmet needs for family planning approximately20\% and above. Of these, 4 countries (Congo Democratic Republic, Gabon and Sao Tome and Principe) were from Central Africa, 5 countries (Burundi, Ethiopia, Tanzania, Uganda, and Comoros) were from East Africa, 2 countries (Eswatini and Zambia) were from Southern Africa and 12 countries (Benin, Burkina Faso, Cameroon, Cote d'Ivoire, Gambia, Ghana, Guinea, Liberia, Mali, Senegal, Sierra Leone, Togo) were from West Africa (Figure 2). The total 
population ofwomen who are married or in unionaged 15 to 49 years from the 37 countries included in this analysis was 322,475 . The country and regional prevalence of unmet needs for the 37 countries is illustrated in Figure 2.

\section{Prevalence of limiting and spacing}

The prevalence of unmet needs for family planningforlimiting was $8 \%(95 \% \mathrm{Cl}: 7-9)$. The highest prevalence of unmet needs forlimitingamong the four sub-regions and within regional countries was observed in East Africa (Prev: 9\%; 95\% Cl: 8-11) with Burundi having the highest prevalence (Prev: 14\%; $95 \% \mathrm{Cl}: 13-14$ ) while Kenya had the least (Prev: $8 \%$; $95 \% \mathrm{Cl}: 8-9$ ). Regionally, the lowest prevalence of unmet needs due to limiting was observed in Central Africa (Prev: 6\%; 95\% Cl: 3-9) (Table 2). Overall, Niger (Prev: 3\%; 95\% Cl: 2-3) had the lowest prevalence of unmet needs due to limiting while Sao Tome and Principe (Prev: $20 \%$; $95 \%$ Cl: 18-22) had the highest. The study further observed that the prevalence ofunmet needs for family planningfor spacing was $15 \%$ (95\% Cl: 14-17). The lowest prevalence of unmet needs for spacing among the regions was observed in Southern Africa (Prev: 12\%; $95 \%$ Cl: 8-16) while the highest was observed in Central Africa (Prev: 18; 95\% Cl: 16-21) (Table 2). Overall, Zimbabwe (Prev: 6\% 95\%; 57) had the lowest prevalence of unmet needs for spacing while Benin (Prev: $23 \%$; $95 \%$ Cl: 22-23) had the highest.A high level of heterogeneity $\left(I^{2}=99 \%\right)$ was observed. Furthermore, there was no publication bias and the Doi plot shows an LFK index of $(0.79)$ which indicates no asymmetry. This means thatthere were significant differences in the prevalence of unmet needs across countries and sub-regions in SSA. (Supplementary file 3).

Table 2: Prevalence of unmet need for spacing and limiting among married women by sub-region

\begin{tabular}{|c|c|c|c|c|}
\hline Variables/Sub-region & Sample size & Prevalence $(95 \% \mathrm{Cl})$ & $P^{2}$ & p-value \\
\hline \multicolumn{5}{|c|}{ Unmet needs for spacing } \\
\hline Central Africa & 41,924 & $6(3,9)$ & 99 & 0.00 \\
\hline East Africa & 68,230 & $9(8,11)$ & 98 & 0.00 \\
\hline Southern Africa & 77,250 & $8(7,10)$ & 98 & 0.00 \\
\hline West Africa & 115,729 & $7(6,9)$ & 99 & 0.00 \\
\hline \multicolumn{5}{|c|}{ Unmet needs for limiting } \\
\hline Central Africa & 41,924 & $18(16,21)$ & 97 & 0.00 \\
\hline East Africa & 68,230 & $14(10,17)$ & 99 & 0.00 \\
\hline Southern Africa & 77,250 & $12(8,16)$ & 100 & 0.00 \\
\hline West Africa & 115,729 & $17(15,19)$ & 98 & 0.00 \\
\hline
\end{tabular}

\section{Prevalence of unmet needs over time}

The overall prevalence of unmet needs for family planningshowed a decrease between the 1995/10 and 2011/15 waves. However, this decrease was not sustained as the prevalence increased from 21\% (95\% Cl: 21-25) observed between 2011-2015 to 24\% (95\% Cl: 21-27) in the 2016-2020 cycles. This trend was similar to the trend in the unmet needs due to limiting. A decrease in prevalence from $8 \%$ (95\%: 4-13) to 7\% (95\% Cl: 7-8) in 1995/10 and 2011/15 waves while in 2016-2020, there was an increase of $1 \%$ to that observed in $201 / 15$ cycles. On the other hand, the prevalence of unmet needs for family planningdue to spacing showed a $1 \%$ increase across the three periods. Between the 1995/10 and 2011/15 waves, the prevalence increased from 14\% (95\% Cl: 9-19) to 15\% (95\% Cl: 12-18) and later to 15\% (95\% Cl: 13-18) in 2016-2020 cycles (Figure 3).

\section{Discussion}

The prevalence of unmet need for family planning is an important metric for designing family planning programs and has implications on maternal and child health.Previous studies have heightened progress in the implementation of family planning at a regional scale[27] however, there are risks of underestimation of the overall prevalence of unmet need for family planning due to 
masking of sub-regional differences. The current study set out to estimate the prevalence of unmet needsfor family planning in women of reproductive age who are married or in a union in the four sub-regions of SSA. Our findings have shown variations in both unmet needsfor family planning across the four regions of SSA.This can be attributed to differences in socio-cultural beliefs and practices, traditional and religious beliefs that prevent acceptance of family planning[28, 29].

Our results also suggest that ending unmet needs for FP by 2030 especially in SSA as set by the United Nations Population Fund (UNFPA)[30] maybe far off unless deliberate policy re-alignment efforts are done. There is a need to improve access and quality of family planning services, enhance monitoring and follow-up of the progress on FP programmes and integration of FP in maternal health programmes. The regional variations in unmet needs for FP observed in our study may also be attributed to regional specific factors relating to social, cultural beliefs and religious beliefs [31]. For instance, in some religious circles, it is considered immoral and sinful to use family planning [28], thus influencing contraceptive decisions.. The observed low prevalence of unmet needs in Southern Africa may be owing to effective design and successful implementation of SRH policies and programmes which have seen increased demand for family planning services in the region[32].

Despite several efforts and initiatives that governmental and non-governmental organizations have implemented in most countries in SSA, our study shows that levels of unmet needs for FP increased between the 2011-2015 to 2016-2020 DHS cycles. This could be attributed to a lack of family planning information among women of reproductive age in Sub-Saharan Africa, which has been necessitated by persistently low educational levels[33,34]. Our study has compared levels of unmet needs for FP across different DHS cycles as a way of determining the progress that had been made by various strategies implemented to address the problem. The increase in the prevalence of unmet needs during the 2016-2020 cycle suggests the need for increased programme monitoring and tracking of success or achievements on an annual basis. An earlier study by Cleland et al. [35]concluded that countries in subSaharan Africa had the greatest need to address unmet needs due to high demand for family planning among women of reproductive age. Our results further suggest the need to enhanced efforts by building on past and present successful interventions to reduce the unmet needs for FP to achieve the SDG targets 3.7.1 and goal 5, to reduce maternal and child morbidity and mortality[4, 36-38]. Reducing the gap in unmet needs goes beyond improving maternal and child health to improving the household and community levelseconomic status. For instance, reducing unmet needs leads to spaced children, increased investment in maternal and child education, acquisition of life skills which maybe essential in income generation [39]. There is a need therefore to emphasize the need to reduce unmet need for FP through enhanced health education and improving access and choices of FP methods.

To help reduce the unmet need for FP in SSA, various initiatives such as the FP2020 by the Bill and Melinda Gates Foundation, the UK Department for International Development, the United States Agency for International Development (USAID), and the United Nations Population Fund $[10,11]$ have been implemented. These programmes have been supplemented by efforts from UNFPA and UNICEF to support national health systems througha steady, reliable supply of quality contraceptives[40]. The differences in the country-level prevalence of unmet needs for FP as observed in our studysuggest the need for governments to ensurea continuous supply of contraceptives and increasing accessibility to sexual and reproductive health services especially among the hard-to-reach populations and adolescents. According to Montoya et al. [41], increasing access to contraceptives reduces maternal mortality as it decreases the risks of unsafe abortions and unintended pregnancies which account for the majority of maternal deaths especially in countries with high unmet needs for FP [42].

The main strength of the study is that it included at least one available latest DHS dataset from all countries with DHS in subSaharan Africa. While some countries had not conducted DHS for some time, their country estimates were essential in understanding the trends that have been achieved in reducing the prevalence of unmet needs for FP. However, some of the limitations stemming from the study are that not all countries in SSA had accessible DHS data. However, estimation of the prevalencebased on the subregions offers a basis for approximation of unmet needs in SSA. Notwithstanding the limitations, our results have underlined huge variation in both country level and sub-regional level prevalence of unmet needs thus generating needs to learn from within the subregions and among countries such as Ethiopia, Kenya, Rwanda, and Zimbabwe that have run successful family planning programs [43].

\section{Conclusion}


Our study highlights the need to improve the availability and accessibility of contraceptives to increase demand and reduce the unmet need. There is need to re-evaluate current FP strategies in the SSA and design new strategies to resolve the problem. Building on past successful programmes, the new strategies should ensure a continuous supply of contraceptives to reduce unmet needs for family planning and associated maternal and child health outcomes in sub-Saharan Africa. There is need for further research to understand best practices regarding SRH programming from better performing countries. The documented practices can be adapted by countries with high unmet needs to improve their situation.

\section{Abbreviations}

Cl Confidence Interval

DHS Demographic and Health Survey

EA Enumeration Area

FP Family Planning

SDG Sustainable Development Goal

SRH Sexual Reproductive Health

SSA Sub-Saharan Africa

UN United Nations

UNFPA United Nations Population Fund

UNICEF United Nations Children Fund

USAID United States Aid for International Development

WHO World Health Organisation

ZDHS Zambia Demographic and Health Survey

\section{Declarations}

Ethical approval and consent to participate

The study used secondary data sources. Permission to use DHS datasets was granted by DHS programme. DHS datasets have no personal identifiers for study participants. All protocols were approved by individual country ethical review bodies and the Center for Disease Control and Prevention (CDC) Atlanta. All DHS's data collection required consent from participants 18 years and older and permission from parents/guardians for participants aged 15-17 years before proceeding to get assent from the adolescent.

\section{Consent for publication}

Not applicable

\section{Availability of data and material}

Data used in this study is readily available at DHS website (www.dhsprogram.com). Other materials such as Do-files can be shared upon request to the corresponding author.

\section{Competing interests}

No competing interests

Funding 
Authors did not receive any funding

\section{Author contribution}

MP developed the concept for the study and sourced the data. MP and CK performed data analysis and wrote the first draft. CO reviewed the manuscript for quality and intellectual content. All authors have read and approved the final manuscript version.

\section{Acknowledgments}

The others are grateful to the DHS program for granting permission to use DHS datasets for 37 countries in SSA

\section{References}

1. UN. Family Planning and the 2030 Agenda for Sustainable Development (data Booklet): UNITED NATIONS DEPARTMENT FOR ECONOMIC SOCIAL AFFAIRS. ; 2019.

2. Kabiru CW, Izugbara CO, Beguy D. The health and wellbeing of young people in sub-Saharan Africa: an under-researched area? BMC international health and human rights. 2013;13(1):1-7.

3. Lang AY, Boyle JA, Fitzgerald GL, Teede H, Mazza D, Moran LJ, Harrison C. Optimizing preconception health in women of reproductive age. Minerva ginecologica. 2017;70(1):99-119.

4. Ahmed S, Li Q, Liu L, Tsui AO. Maternal deaths averted by contraceptive use: an analysis of 172 countries. The Lancet. 2012;380(9837):111-25.

5. Ajayi Al, Adeniyi OV, Akpan W. Maternal health care visits as predictors of contraceptive use among childbearing women in a medically underserved state in Nigeria. Journal of Health, Population and Nutrition. 2018;37(1):1-10.

6. Singh S, Darroch JE. Adding it up: costs and benefits of contraceptive services-estimates for 2012. 2012.

7. Edietah EE, Njotang PN, Ajong AB, Essi MJ, Yakum MN, Mbu ER. Contraceptive use and determinants of unmet need for family planning; a cross sectional survey in the North West Region, Cameroon. BMC women's health. 2018;18(1):1-8.

8. Gebre G, Birhan N, Gebreslasie K. Prevalence and factors associated with unmet need for family planning among the currently married reproductive age women in Shire-Enda-Slassie, Northern West of Tigray, Ethiopia 2015: a community based crosssectional study. Pan African Medical Journal. 2016;23(1).

9. Rana MJ, Goli S. The road from ICPD to SDGs: health returns of reducing the unmet need for family planning in India. Midwifery. 2021:103107.

10. Brown W, Druce N, Bunting J, Radloff S, Koroma D, Gupta S, Siems B, Kerrigan M, Kress D, Darmstadt GL. Developing the " 120 by 20" goal for the Global FP2020 Initiative. Studies in family Planning. 2014;45(1):73-84.

11. Anderson T. Providing family planning services to women in Africa. Bulletin of the World Health Organization. 2017;95(9):614-6.

12. UNFPA. Universal Access to Reproductive Healthcare: Progress and Challenges. New York; 2016: UNPF; 2019.

13. Bongaarts $\mathrm{J}$, Hardee $\mathrm{K}$. The role of public-sector family planning programs in meeting the demand for contraception in SubSaharan Africa. International perspectives on sexual and reproductive health. 2017;43(2):41-50.

14. Ajong AB, Njotang PN, Yakum MN, Essi MJ, Essiben F, Eko FE, Kenfack B, Mbu ER. Determinants of unmet need for family planning among women in Urban Cameroon: a cross sectional survey in the Biyem-Assi Health District, Yaoundé. BMC women's health. 2015;16(1):1-8.

15. Yaya S, Idriss-Wheeler D, Uthman OA, Bishwajit G. Determinants of unmet need for family planning in Gambia \& Mozambique: implications for women's health. BMC women's health. 2021;21(1):1-8.

16. Haider TL, Sharma M. Barriers to family planning and contraception uptake in sub-Saharan Africa: a systematic review. International quarterly of community health education. 2013;33(4):403-13.

17. Wulifan JK, Brenner S, Jahn A, De Allegri M. A scoping review on determinants of unmet need for family planning among women of reproductive age in low and middle income countries. BMC women's health. 2015;16(1):1-15.

18. Ahinkorah BO, Ameyaw EK, Seidu A-A. Socio-economic and demographic predictors of unmet need for contraception among young women in sub-Saharan Africa: evidence from cross-sectional surveys. Reproductive health. 2020;17(1):1-11. 
19. Long JE, Waruguru G, Yuhas K, Wilson KS, Masese LN, Wanje G, Kinuthia J, Jaoko W, Mandaliya KN, McClelland RS. Prevalence and predictors of unmet contraceptive need in HIV-positive female sex workers in Mombasa, Kenya. PloS one.

2019;14(6):e0218291.

20. Mekie M, Addisu D, Taklual W, Melkie A. The Level of Unmet Need for Family Planning and Its Predictors among HIV-Positive Women in Ethiopia: A Systematic Review and Meta-Analysis. BioMed Research International. 2021;2021.

21. Kefale B, Adane B, Damtie Y, Arefaynie M, Yalew M, Andargie A, Addisu E. Unmet need for family planning among reproductiveage women living with HIV in Ethiopia: A systematic review and meta-analysis. PloS one. 2021;16(8):e0255566.

22. Ahn E, Kang H. Introduction to systematic review and meta-analysis. Korean journal of anesthesiology. 2018;71(2):103.

23. Suurmond R, van Rhee H, Hak T. Introduction, comparison, and validation of Meta-Essentials: a free and simple tool for metaanalysis. Research synthesis methods. 2017;8(4):537-53.

24. DHS. The DHS program [Available from: www.dhsprogram.com.

25. Barendregt J, Doi S. MetaXL User Guide version 5.3. EpiGear International Pty Ltd. 2016.

26. Doi S, Barendregt J, Khan S, Thalib L, Williams G. Advances in the Meta-analysis of heterogeneous clinical trials I: The inverse variance heterogeneity model. Contemp Clin Trials. 2015;45:130-8.

27. Sharan M, Ahmed S, May J, Soucat A. Family planning trends in Sub-Saharan Africa: progress, prospects, and lessons learned. Yes Africa Can. 2011;445:258643-1271798012256.

28. Ataullahjan A, Mumtaz Z, Vallianatos H. Family planning, Islam and sin: Understandings of moral actions in Khyber Pakhtunkhwa, Pakistan. Social Science \& Medicine. 2019;230:49-56.

29. Pinter B, Hakim M, Seidman DS, Kubba A, Kishen M, Di Carlo C. Religion and family planning. The European Journal of Contraception \& Reproductive Health Care. 2016;21(6):486-95.

30. UNFPA. UNFPA's Consultation on Ending Unmet Need for Family Planning. Antalya, Turkey2019.

31. Coleman M, Alonso A. A qualitative study exploring how family planning beliefs and attitudes contribute to family planning behavior in rural, southeastern Kenya: application of the social ecological model. World Medical \& Health Policy. 2016;8(4):36481.

32. Ooms GI, Kibira D, Reed T, van den Ham HA, Mantel-Teeuwisse AK, Buckland-Merrett G. Access to sexual and reproductive health commodities in East and Southern Africa: a cross-country comparison of availability, affordability and stock-outs in Kenya, Tanzania, Uganda and Zambia. BMC public health. 2020;20(1):1-14.

33. Gahungu J, Vahdaninia M, Regmi PR. The unmet needs for modern family planning methods among postpartum women in SubSaharan Africa: a systematic review of the literature. Reproductive Health. 2021;18(1):1-15.

34. Alege SG, Matovu JK, Ssensalire S, Nabiwemba E. Knowledge, sources and use of family planning methods among women aged 15-49 years in Uganda: a cross-sectional study. Pan African Medical Journal. 2016;24(1).

35. Cleland J, Shah IH, Benova L. A fresh look at the level of unmet need for family planning in the postpartum period, its causes and program implications. International perspectives on sexual and reproductive health. 2015;41(3):155-62.

36. Shah IH, Say L. Maternal mortality and maternity care from 1990 to 2005: uneven but important gains. Reproductive health matters. 2007;15(30):17-27.

37. Cleland J, Conde-Agudelo A, Peterson H, Ross J, Tsui A. Contraception and health. The Lancet. 2012;380(9837):149-56.

38. Stover J, Ross J. How increased contraceptive use has reduced maternal mortality. Maternal and child health journal. 2010;14(5):687-95.

39. Canning D, Schultz TP. The economic consequences of reproductive health and family planning. The Lancet. 2012;380(9837):165-71.

40. UNFPA. Family planning 2020 [Available from: https://www.unfpa.org/family-planning.

41. Montoya A, Calvert C, Filippi V. Explaining differences in maternal mortality levels in sub-Saharan African hospitals: a systematic review and meta-analysis. International Health. 2014;6(1):12-22.

42. Ashford L. Unmet need for family planning: Recent trends and their implications for programs: Population Reference Bureau Washington, DC; 2003. 
43. May JF. The politics of family planning policies and programs in sub-Saharan Africa. Population and development review. 2017;43:308-29.

\section{Figures}

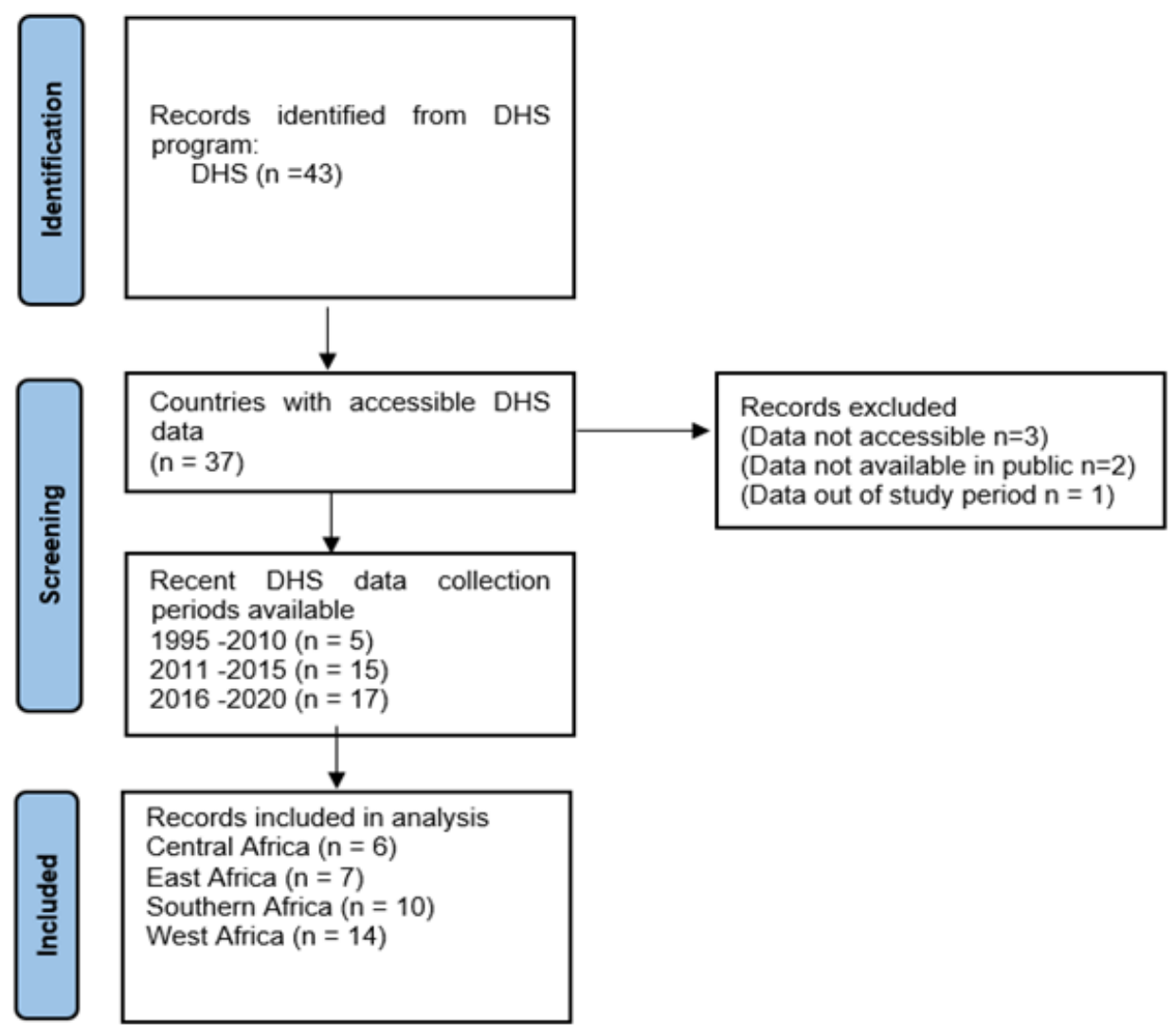

Figure 1

PRISMA flow diagram of selected countries included in the study 


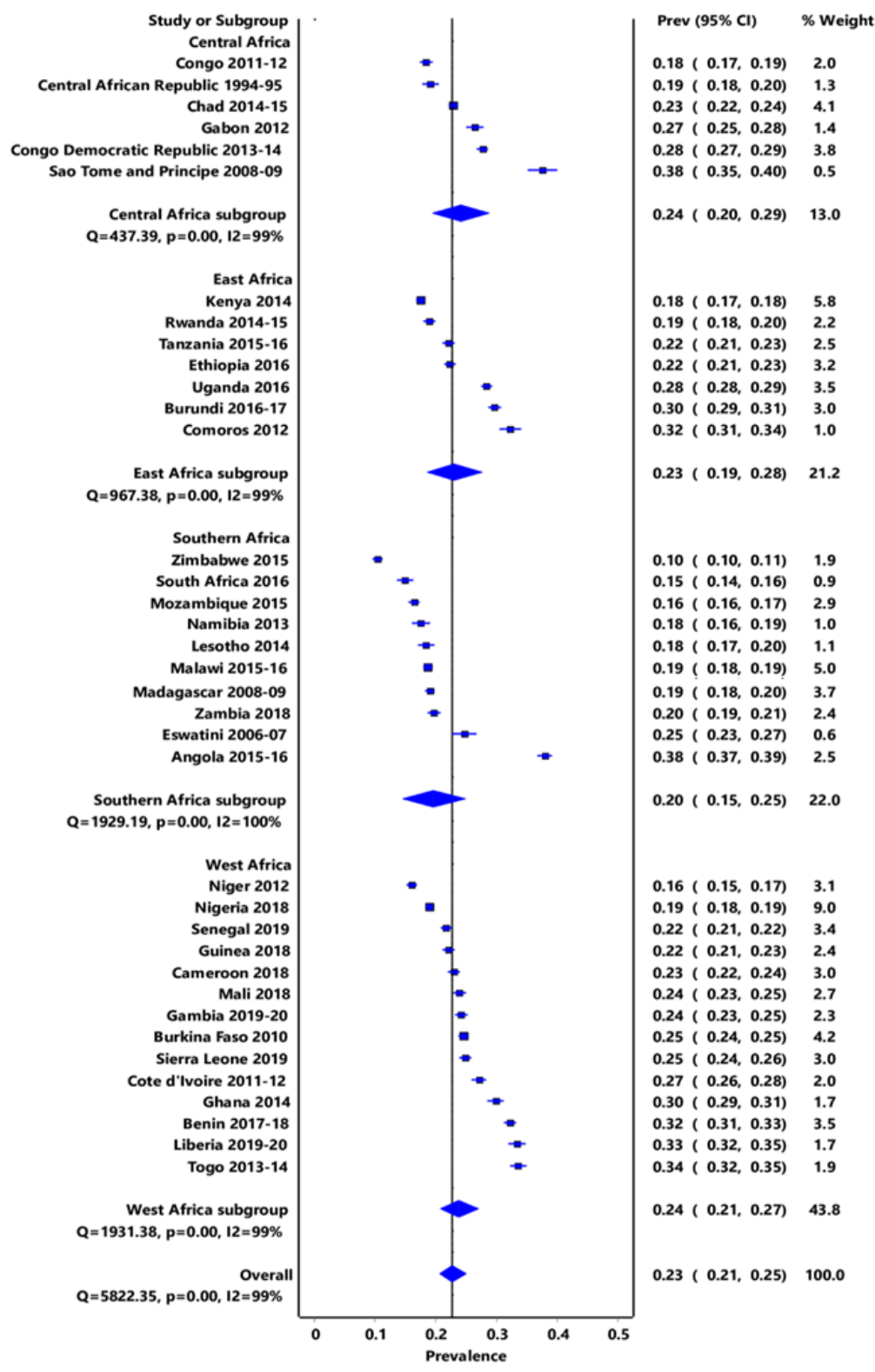

Figure 2

Pooled prevalence of unmet need for family planning in sub-Saharan Africa 


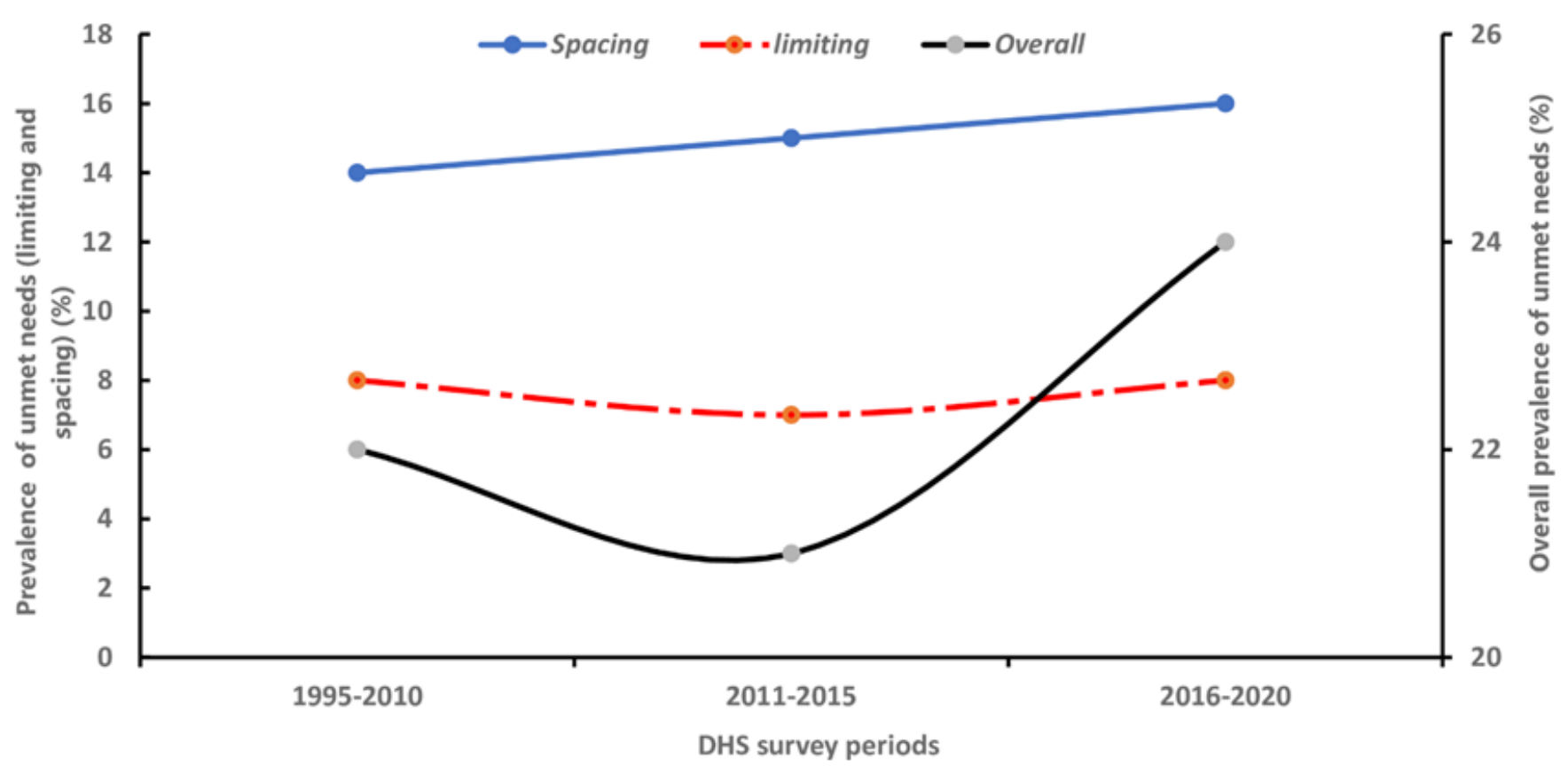

Figure 3

Pooled prevalence of unmet needs for family planning in sub-Saharan Africa by DHS period

\section{Supplementary Files}

This is a list of supplementary files associated with this preprint. Click to download.

- Supplementaryfiles.docx 